\title{
Differential Response of Potato Toward Inoculation with Taxonomically Diverse Plant Growth Promoting Rhizobacteria
}

\author{
Tahir Naqqash ${ }^{1,2}$, Sohail Hameed ${ }^{1 *}$, Asma Imran1, Muhammad Kashif Hanif1, \\ Afshan Majeed ${ }^{1,3}$ and Jan Dirk van Elsas ${ }^{4}$
}

\begin{abstract}
${ }^{1}$ National Institute for Biotechnology and Genetic Engineering, Faisalabad, Pakistan, ${ }^{2}$ Pakistan Institute of Engineering and Applied Sciences, Islamabad, Pakistan, ${ }^{3}$ University of Poonch, Rawlakot, Pakistan, ${ }^{4}$ Department of Microbial Ecology, Groningen Institute for Evolutionary Life Sciences, University of Groningen, Groningen, Netherlands
\end{abstract}

OPEN ACCESS

Edited by:

Sagadevan G. Mundree, Queensland University of Technology, Australia

Reviewed by: Ezequiel Matias Lentz, ETH Zurich, Switzerland

Gyöngyvér Mara, Sapientia Hungarian University of Transylvania, Romania

*Correspondence:

Sohail Hameed shameed58@hotmail.com

Specialty section: This article was submitted to Plant Biotechnology, a section of the journal Frontiers in Plant Science

Received: 07 August 2015 Accepted: 28 January 2016 Published: 17 February 2016

Citation:

Naqqash T, Hameed S, Imran A, Hanif MK, Majeed A and van Elsas JD (2016) Differential Response of Potato Toward Inoculation with Taxonomically Diverse Plant Growth Promoting Rhizobacteria. Front. Plant Sci. 7:144. doi: 10.3389/fpls.2016.00144
Rhizosphere engineering with beneficial plant growth promoting bacteria offers great promise for sustainable crop yield. Potato is an important food commodity that needs large inputs of nitrogen and phosphorus fertilizers. To overcome high fertilizer demand (especially nitrogen), five bacteria, i.e., Azospirillum sp. TN10, Agrobacterium sp. TN14, Pseudomonas sp. TN36, Enterobacter sp. TN38 and Rhizobium sp. TN42 were isolated from the potato rhizosphere on nitrogen-free malate medium and identified based on their 16S rRNA gene sequences. Three strains, i.e., TN10, TN38, and TN42 showed nitrogen fixation (92.67-134.54 $\mathrm{nmol} \mathrm{h}{ }^{-1} \mathrm{mg}^{-1}$ protein), while all showed the production of indole-3-acetic acid (IAA), which was significantly increased by the addition of Ltryptophan. Azospirillum sp. TN10 produced the highest amount of IAA, as measured by spectrophotometry $\left(312.14 \mu \mathrm{g} \mathrm{mL}^{-1}\right)$ and HPLC $\left(18.3 \mu \mathrm{g} \mathrm{mL}^{-1}\right)$. Inoculation with these bacteria under axenic conditions resulted in differential growth responses of potato. Azospirillum sp. TN10 incited the highest increase in potato fresh and dry weight over control plants, along with increased $\mathrm{N}$ contents of shoot and roots. All strains were able to colonize and maintain their population densities in the potato rhizosphere for up to 60 days, with Azospirillum sp. and Rhizobium sp. showing the highest survival. Plant root colonization potential was analyzed by transmission electron microscopy of root sections inoculated with Azospirillum sp. TN10. Of the five test strains, Azospirillum sp. TN10 has the greatest potential to increase the growth and nitrogen uptake of potato. Hence, it is suggested as a good candidate for the production of potato biofertilizer for integrated nutrient management.

Keywords: PGPR, Azospirillum, potato, $\mathrm{N}_{2}$-fixation, IAA, TEM, plant inoculation

\section{INTRODUCTION}

Potato (Solanum tuberosum L.), of the family Solanaceae, is the third most important food crop in the world after rice and wheat. More than a billion people worldwide consume potato, and global crop production exceeds 350 million metric tons (Food and Agriculture Organization, 2014). It is a high fertilizer-demanding crop, which requires $250 \mathrm{~kg} \mathrm{ha}^{-1}$ of nitrogen and $150 \mathrm{~kg} \mathrm{ha}^{-1}$ of phosphorus to get an optimum yield 
(George and Ed, 2011). These requirements not only increase the cost of production but also cause severe environmental problems (David et al., 2002). A more ecologically friendly and economical approach to this problem may lie in the exploitation of the rhizosphere microbiome. Soil microbes constitute a largely unexplored biochemical wealth which have a profound role in biogeochemical cycles and may directly or indirectly impact on the nutrient status of soil (Khosro and Yousef, 2012).

Rhizobacteria are plant-associated bacteria that are able to colonize and persist in the vicinity of, on, or inside the roots of plants. Due to the often raised nutritional concentrations and root exudates, plant roots serve as 'microbial hot spots' in the soil. The rhizobacteria can colonize different sites of the rhizosphere (e.g., the root surface or interior) and directly or indirectly stimulate plant growth. When introduced to seeds, roots or into the soil, these bacteria, which include plant-growth- promoting rhizobacteria (PGPR) can solubilize insoluble phosphates, produce plant growth hormones, convert atmospheric nitrogen to ammonia or suppress the growth of plant pathogens (Pérez-Montaño et al., 2013). Alcaligenes, Agrobacterium, Arthrobacter, Azospirillum, Azotobacter, Bacillus, Bradyrhizobium, Burkholderia, Enterobacter, Frankia, Klebsiella, Pseudomonas, Rhizobium, and Serratia are genera that encompass common PGPR with known benefits on different crop plants (Bhattacharyya and Jha, 2012; Tailor and Joshi, 2014). Research on PGPR has been increasing and a number of experiments, both in vitro and in vivo, have been carried out on different crops. This has included wheat (Majeed et al., 2015), rice (Lucas et al., 2009), maize (Qaisrani et al., 2014), soybean (Cassán et al., 2009), sunflower (Shahid et al., 2012), and bean (Pérez-Montaño et al., 2013). These studies have shown the potential of PGPR to foster the growth and yield of such crops, with minor inputs of agrochemicals and lowered consequences for the environment.

The rhizosphere engineering of potato using PGPR still leaves a lot to be desired. Limited data are as yet available with respect to PGPR colonization, disease suppression (Andreote et al., 2009; Ghyselinck et al., 2013) and growth promotion (Mohammed et al., 2013) in potato. The reported PGPR from potato include mostly Bacillus and Pseudomonas sp. that have been used for improving phosphorus uptake (Hanif et al., 2015), production of indole acetic acid (IAA) and biocontrol activity (Calvo et al., 2010; Hunziker et al., 2015) and induced systemic resistance (Ardanov et al., 2011). Rhizobium-induced systemic resistance has also been reported in potato (Reitz et al., 2001). Although Azospirillum sp. have been reported to be associated with the rhizosphere of a number of crops, up till now no data are available with respect to the association of this genus with potato.

We have isolated bacteria from potato growing areas of central Punjab, Pakistan. These areas are geographically heterogeneous and share up to $80 \%$ of the total potato production of the country. It was hypothesized that the rhizosphere microbiome of these sites may contain a variety of potential PGPR that can augment plant growth especially potato. With this aim, taxonomically diverse bacteria were obtained and a comparative study was conducted for their functional characterization, potato tuber inoculation response and nitrogen uptake. We describe the potential of Azospirillum for growth promotion of potato. To the best of our knowledge, this is the first report of Azospirillum association with potato roots.

\section{MATERIALS AND METHODS}

\section{Soil Sampling and Bacterial Isolations}

Potato rhizospheric soil samples were collected from two different areas of Punjab, Pakistan, i.e., Jhang (N: $31^{\circ} 13.712^{\prime}$, E: $072^{\circ} 16.080^{\prime}, 134 \mathrm{~m}$ above sea level) and Sahiwal (N: $30^{\circ} 37.707^{\prime}$ E: $73^{\circ} 01.203^{\prime}, 157 \mathrm{~m}$ above sea level). Samples were immediately placed on dry ice and transferred to the laboratory for further work. Nitrogen-free malate (NFM) semi-solid medium was used for the isolation of diazotrophic bacteria (Okon et al., 1977). Potato root pieces along with rhizosphere soil were introduced into $5 \mathrm{~mL}$ of NFM medium in glass vials. After $48 \mathrm{~h}$ of incubation at $28 \pm 2^{\circ} \mathrm{C}, 100 \mu \mathrm{L}$ from each vial were transferred to a fresh vial containing semi-solid NFM. For enrichment, this procedure was repeated at least six times and then a loopful of culture was streaked on NFM agar plates. Single colonies were picked from these plates, streaked and purified by repeated sub-culturing on fresh Luria Bertani (LB) agar plates. The purified isolates were maintained on LB agar plates for further studies. Isolates were stored in $20 \%(\mathrm{v} / \mathrm{v})$ glycerol at $-80^{\circ} \mathrm{C}$.

\section{Morphological Characterization}

Colony morphology of purified bacterial isolates was studied by streaking on LB agar plates, followed by incubation of the plates at $28 \pm 2{ }^{\circ} \mathrm{C}$ for $24 \mathrm{~h}$. The cell shape and motility of the bacterial strains were observed using light microscopy (Nikon LABOPHOTO-2, Japan). Gram staining was done as described by Vincent (1970).

\section{Phenotypic Microarray}

The metabolic potential of the Azospirillum sp. TN10 was evaluated by using BIOLOG GN2 microplates (Müller and Ehlers, 2007). Strain TN10 was grown on LB agar plates for $48 \mathrm{~h}$ at $28 \pm 2^{\circ} \mathrm{C}$. It was then harvested in $1.5 \mathrm{~mL}$ Eppendorf tubes containing $1 \mathrm{~mL}$ of DEPC water and starved for $3 \mathrm{~h}$. The culture was then mixed with inoculation fluid IF-0a and a redox indicator as per the manufacturer's instruction. $100 \mu \mathrm{L}$ were added to each of the 96 wells in the carbon utilization plate, PM2A (Biolog, Hayward, CA, USA). The plates were incubated at $28 \pm 2{ }^{\circ} \mathrm{C}$ for $24 \mathrm{~h}$ and observed on a VERSA max micro-plate reader (Molecular Devices, USA) with softmax pro-software for qualitative and quantitative analysis (Line et al., 2011).

\section{Identification and Phylogenetic Analysis of Bacteria Based on 16S rRNA Gene Sequence}

Genomic DNA was extracted using the UltraClean Microbial DNA Isolation Kit (Mo Bio Laboratories, Inc., New York) according to the manufacturer's instructions. The 16S rRNA gene was amplified with primers fD1 and rD1 (Weisburg et al., 1991), using conditions described by Shahid et al. 
(2012) in a thermal cycler (PeQLab, advanced Primus 96). Purified PCR products were sequenced commercially (Eurofins, Germany). The sequenced products were analyzed using sequence scanner software package. Both ends were joined by Cap 3 assembly software and examined by NCBI BLAST (http: //blast.ncbi.nlm.nih.gov/Blast.cgi) against the GenBank database. Multiple sequence alignment was performed and phylogeny was determined by neighbor-joining using MEGA6 software package (Tamura et al., 2013).

\section{Quantification of Nitrogen Fixation}

Bacterial isolates were assessed for their nitrogen fixing ability using the acetylene reduction assay (ARA) as described by Hardy et al. (1968). Each isolate was grown in NFM semisolid medium for $72 \mathrm{~h}$ at $28 \pm 2^{\circ} \mathrm{C}$ and evaluated for nitrogenase activity by gas chromatography (Thermoquest, Trace GC, Model K, Rodon Milan, Italy) using a Porapak $\mathrm{N}$ column and flame ionization detector (FID), following the standard protocol described by Park et al. (2005). The nitrogenase activity of the isolates was expressed as nmoles of ethylene formed per $\mathrm{h}$ per $\mathrm{mg}$ of protein.

\section{Production of Indole-3-Acetic Acid (IAA)}

Indole acetic acid production ability was determined by colorimetric analysis and HPLC. The test was performed both in the presence and absence of L-tryptophan as precursor of IAA. One hundred $\mathrm{mL} \mathrm{LB}$ broth in $250 \mathrm{ml}$ Erlenmeyer flasks was inoculated with $100 \mu \mathrm{l}$ of overnight bacterial culture, adjusted to optical density $0.6\left(10^{7}-10^{8} \mathrm{CFU} \mathrm{ml}{ }^{-1}\right)$ measured at $600 \mathrm{~nm}$ (Camspec M350 double beam UV Visible, UK). The bacteria were grown at $28 \pm 2^{\circ} \mathrm{C}$ for $72 \mathrm{~h}$ with continuous shaking at $150 \mathrm{rpm}$. Supernatant was collected by centrifuging at $4000 \times g$ for $15 \mathrm{~min}$. Half of the supernatant $(\approx 50 \mathrm{ml})$ was filtered through $0.2 \mu \mathrm{m}$ nylon filters (Millipore, USA). IAA was detected by mixing $100 \mu \mathrm{L}$ of Salkowski reagent $(1 \mathrm{ml} 0.5 \mathrm{M} \mathrm{FeCl}$, $30 \mathrm{ml}$ concentrated $\mathrm{H}_{2} \mathrm{SO}_{4}$ and $50 \mathrm{ml}$ distilled $\mathrm{H}_{2} \mathrm{O}$ ) with $100 \mu \mathrm{L}$ of filtered supernatant and allowed to react at room temperature for $20 \mathrm{~min}$. IAA production was confirmed by pink color development as quantified at $540 \mathrm{~nm}$ (Camspec M350 double beam UV Visible, UK). A standard graph was prepared against concentrations 10,20,30,40,50, and 100 ppm IAA (Sachdev et al., 2009). Blanks (LB broth medium and Salkowski reagent) showing yellow color were below the detection limit. The remaining half of the supernatant $(\approx 50 \mathrm{ml})$ was acidified to $\mathrm{pH} 2.8$ with $1 \mathrm{~N}$ hydrochloric acid and extracted three times with equal volumes of ethyl acetate (Tien et al., 1979). The extract was analyzed on HPLC (Perkin Elmer, USA) fitted with C-18 column, using methanol $(30: 70 \mathrm{v} / \mathrm{v})$ mobile phase at a flow rate of $0.5 \mathrm{~mL} \mathrm{~min}^{-1}$ as described (Shahid et al., 2014).

\section{Analysis of nifH Gene}

Nested PCR was used for nifH gene amplification following Pereira e Silva et al. (2011). The first PCR was carried out with primers FPGH19, 5'-TACGGCAARGGTGGNAT HG-3'; (Simonet et al., 1991) and PolR, 5'-ATSGCCATCATYTC RCCGGA-3' (Poly et al., 2001) that resulted in a product of $490 \mathrm{bp}$. Two $\mu \mathrm{L}$ of this first PCR product were used as the template in the second reaction with primers PolF, $5^{\prime}$ TGCGAYCCSAARGCBGACTC- $3^{\prime}$ and AQER, 5'-GACGAT GATYTCCTG-3' (Poly et al., 2001). To confirm amplification of the desired PCR product, amplicons were run on 1.5\% agarose gels in TAE buffer (20 mM Tris, $10 \mathrm{mM}$ acetate, $0.5 \mathrm{mM}$ EDTA; $\mathrm{pH}$ 8.0) along with a 1-kb DNA ladder (Promega, Leiden, the Netherlands). PCR products were purified using the QIAquick PCR purification kit (Qiagen, USA) and sent to Macrogen (Seoul, Korea) for sequencing. The sequenced product was analyzed in the same way as described for the $16 \mathrm{~S}$ rRNA gene. The Molecular Modeling Database (MMDB) from NCBI combined with the software $\mathrm{Cn} 3 \mathrm{D}$ (NCBI) was used to model the $3 \mathrm{D}$ structure of the nitrogenase encoded by the nifH gene.

\section{Plant Inoculation Experiments}

The bacterial strains were grown in $100 \mathrm{~mL}$ of LB for $24 \mathrm{~h}$ at $28 \pm 2{ }^{\circ} \mathrm{C}$. After growth, cells were harvested by centrifugation at $4000 \times g$ for $20 \mathrm{~min}$ at $4^{\circ} \mathrm{C}$ and resuspended in $100 \mathrm{~mL}$ of sterile saline $(0.89 \% \mathrm{w} / \mathrm{v} \mathrm{NaCl}$ in water). In order to evaluate plant growth promotion activities, medium-sized $(2-3 \mathrm{~cm})$ tubers of potato (variety Kuroda) were used. Potato tubers were thus surface-sterilized with sodium hypochlorite $(10 \% \mathrm{v} / \mathrm{v})$ for $8 \mathrm{~min}$ followed by extensive washing with sterilized distilled water. Sand was also sterilized by soaking in $0.5 \mathrm{~N}$ nitric acid for $24 \mathrm{~h}$, washed thoroughly to remove acid, dried and then autoclaved.

There were five bacterial inoculation treatments along with one uninoculated control treatment, each with four replicates. Single tubers, with more than two eye buds, were dipped in the

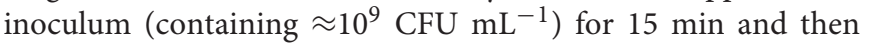
placed in pots containing $600 \mathrm{~g}$ of sand, after which pots were placed in a growth room $\left(16 / 8 \mathrm{~h}\right.$ light/dark and $20 / 8^{\circ} \mathrm{C}$ day/night temperature). A second inoculation was done at day 15 after seedling emergence, by mixing inocula in half-strength Hoagland solution (Arnon and Hoagland, 1940) at rates of $2 \mathrm{~mL}$ per pot. Plants were irrigated with Hoagland solution and sterilized water (1:1) every $48 \mathrm{~h}$ (150 mL per pot). Plants were harvested after 60 days and measurements were made of shoot and root length, and fresh and dry weights. Colonization by inoculant strains was evaluated by recovering cells from the respective rhizospheres on LB plates. Careful uprooting of the potato plants with intact roots was used, followed by gentle shaking in sterile distilled water to remove the loosely adhered sand. Bacteria were recovered by dilution plating technique using $1 \mathrm{~g}$ of strongly adhering sand in $9 \mathrm{~mL}$ sterile water (Seldin et al., 1998).

\section{Ultrastructure Studies}

Roots from the above experiment were washed with sterile distilled water to remove the sand particles. They were then cut into pieces $(\sim 1-3 \mathrm{~cm})$ and embedded in water agar, followed by cutting out $\sim 2-3 \mathrm{~mm}$ agar cubes. The cubes were put in $1.5 \mathrm{~mL}$ tubes in the presence of $5 \%$ gluteraldehyde as a fixative for $16-18 \mathrm{~h}$, after which the fixative was replaced with $0.2 \mathrm{M}$ PIPES buffer (Salema and Brandao, 1973). After washing twice for $1 \mathrm{~h}$ with fresh buffer, samples were treated with $0.2 \%$ osmium tetraoxide, dissolved in PIPES buffer for 16-18 h and again washed twice for $30 \mathrm{~min}$ with sterile distilled water. After being treated with $5 \%$ aqueous uranyl acetate for $16-18 \mathrm{~h}$, the samples 
were washed twice with sterile distilled water for $30 \mathrm{~min}$. The samples were then immersed twice in absolute ethanol for $30 \mathrm{~min}$, followed by immersion in propylene oxide (100\%) for $30 \mathrm{~min}$ for dehydration. Infiltration of samples was carried out with propylene oxide at a ratio of 1:1 for 24-48 h and then with spur resin for a further $24-72 \mathrm{~h}$, using benzyl dimethyl amine as the accelerator in all infiltration steps. The samples were polymerized for $72 \mathrm{~h}$ at $70^{\circ} \mathrm{C}$ on flat embedded molds, followed by incubation at room temperature for at least $24 \mathrm{~h}$ before cutting. Sections (150-200 nm) were cut using an ultra-microtome (RMC-7000; Boeckeler Instruments, USA) and carefully placed on copper grids. Sections were then double-stained with uranyl acetate (30 $\mathrm{min})$ and lead citrate (10 $\mathrm{min})$, washed with deionized water and observed under transmission electron microscope (TEM; JEOL JEM 1010, USA).

\section{Statistical Analyses}

Data on different plant parameters of the pot experiment were analyzed statistically by analysis of variance (ANOVA; Steel et al., 1997) using STATISTIX 8.1 software (Tallahassee, FL, USA). Treatment means were compared by applying least significant difference tests (LSD) at 5\% probability.

\section{RESULTS}

\section{Isolation, Characterization, and Identification of Rhizobacteria}

Rhizospheric soil samples were collected from Jhang and Sahiwal, which are major potato growing areas of Punjab, Pakistan. Five bacterial strains were purified from enrichment culture on NFM semisolid medium. Table 1 shows the morphological and physiological characteristics of these bacteria. Bacterial isolates TN10 and TN14 were obtained from Jhang and showed pink, round colonies with vibroid motile cells and convex, round colonies with motile rods, respectively. The other bacterial isolates, TN36, TN38 and TN42, were obtained from Sahiwal and showed round colonies which contained motile short rods, except TN42 which was non-motile. All isolates were Gram-negative. Bacterial isolate TN10 utilized 52 carbon sources out of 95 in the PM2A, BIOLOG microplate, showing a very diverse metabolic potential.

Based on 16S rRNA gene sequence analyses, bacterial isolate TN10 was presumptively identified as Azospirillum sp., TN14 as Agrobacterium sp., TN36 as Pseudomonas sp., TN38 as Enterobacter sp., while TN42 was a Rhizobium sp., all showing 99\% homologies with the respective sequences in the GenBank database (Table 1). The 16S rRNA gene sequences were submitted to GenBank (nucleotide database) under the accession numbers LN614537, LN614534, LN614533, LN614535, and LN614536. Phylogenetic analyses using neighbor-joining showed two main clusters ( $\alpha$-proteobacteria and $\gamma$-proteobacteria) and four subclusters, with high bootstrap values (Figure 1). Strain TN14 and strain TN42 belong to Rhizobium, strain TN10 clustered in an Azospirillum clade, while strains TN38 and TN36 were affiliated with Enterobacter and Pseudomonas, respectively, at bootstrap values $>95 \%$ with reference strains from the NCBI database (Figure 1).

\section{Nitrogenase Activity Measured by ARA and Phylogenetic Analysis of the nifH Gene}

The ARA showed that Azospirillum sp. TN10, Pseudomonas sp. TN36, and Rhizobium sp. TN42 were positive for nitrogenase activity; strain TN10 showed the highest activity (Table 1).

Of three nitrogen-fixing strains, we could amplify the nifH gene only from Azospirillum sp. TN10. The $360 \mathrm{bp}$ fragment was obtained and sequenced, after which the sequence was compared with GenBank database sequences. The sequence showed 99\% similarity with an Azospirillum brasilense partial nifH gene, which encodes a nitrogenase iron protein (Acc. No. FR669137). Phylogenetic analysis based on neighbor-joining using the nifH gene sequence of strain $\mathrm{TN} 10$ and sequences from different Azospirillum genera showed that the nifH sequence of strain TN10 (LN681358) was affiliated with that of A. brasilense at a bootstrap value of 92 (Figure 2). The predicted 3D structure of the nitrogenase protein was $77 \%$ similar to a nitrogenase Feprotein described for Azotobacter vinelandii (NCBI, PDB. Acc.

TABLE 1 | Morphological characteristics of the bacterial isolates from potato and their identification on the basis of $16 \mathrm{~S}$ rRNA gene sequence analysis.

\begin{tabular}{|c|c|c|c|c|c|}
\hline Isolate code & Colony morphology & Cell morphology & ARA & $\begin{array}{l}\text { Maximum similarity } \\
\text { of } 16 \mathrm{~S} \text { rRNA with (\%) }\end{array}$ & $\begin{array}{l}\text { GenBank accession } \\
\text { no. of } 16 S \text { rRNA gene }\end{array}$ \\
\hline TN 10 & Pink, round & Vibroid rods & $134.54 \pm 13.99$ & $\begin{array}{l}\text { Azospirillum sp. } \\
\text { FR667907 (99\%) }\end{array}$ & LN614537 \\
\hline TN 14 & Convex, round & Rods & $-v e$ & $\begin{array}{l}\text { Agrobacterium sp. } \\
\text { JN628031 (99\%) }\end{array}$ & LN614534 \\
\hline TN 36 & Mucoid, round & Short rods & $-v e$ & $\begin{array}{l}\text { Pseudomonas sp. } \\
\text { EF540467 (99\%) }\end{array}$ & LN614533 \\
\hline TN 42 & Milky, round & Rods & $92.67 \pm 8.42$ & $\begin{array}{l}\text { Rhizobium sp. } \\
\text { HG518323 (99\%) }\end{array}$ & LN614536 \\
\hline
\end{tabular}

All strains were motile except TN42. ARA, acetylene reduction assay (nmol $\mathrm{h}^{-1} \mathrm{mg}^{-1}$ of protein). Values are averages of three independent replications. Standard errors of the means are mentioned between parentheses. 


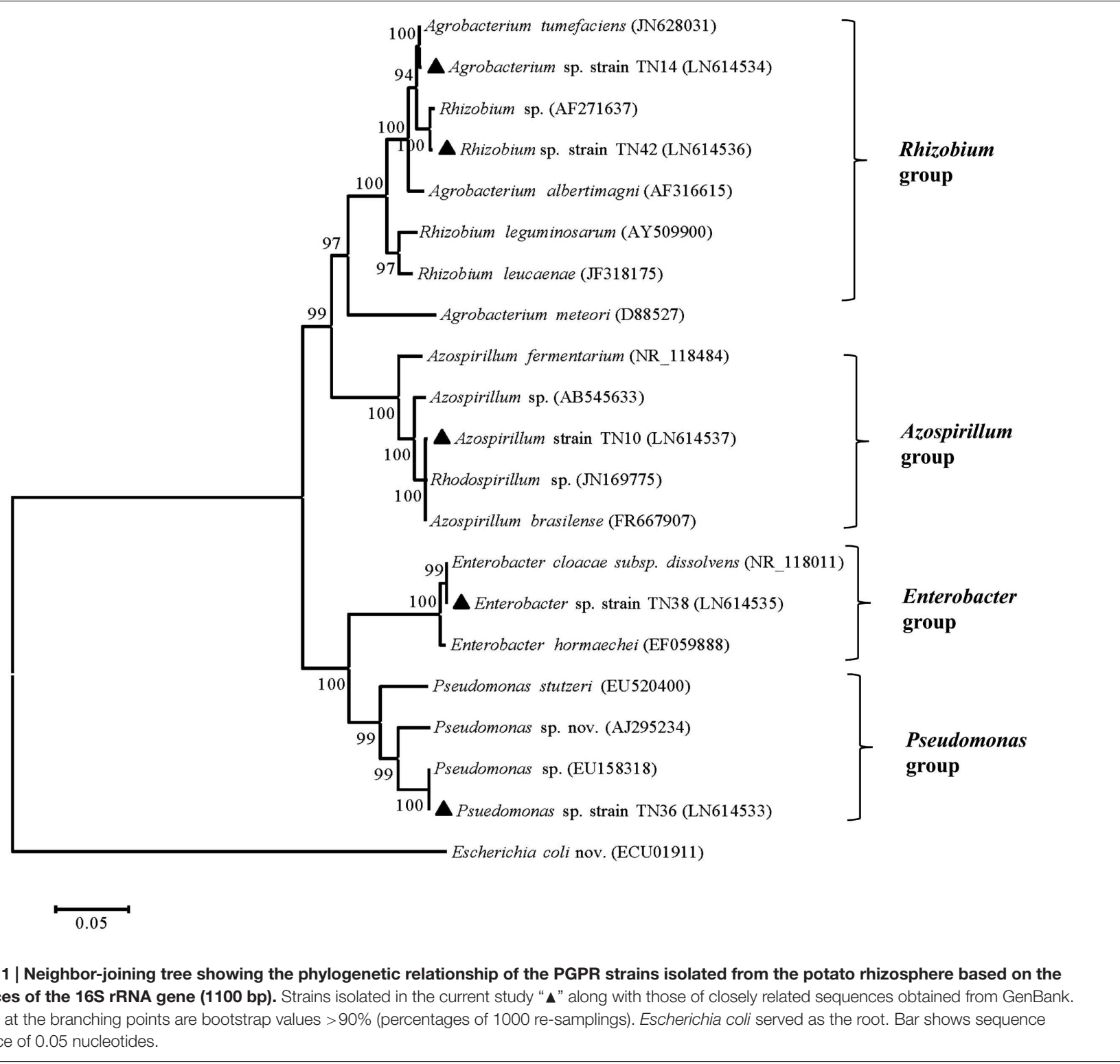

No. 1RW4). This structure was modeled using MMDB from NCBI combined with the software Cn3D 4.3 (Figure 3).

\section{Quantification of IAA Produced by the Novel Bacterial Strains}

The Salkowski assay showed the production of IAA by all the bacterial strains with or without L-tryptophan induction. However, the amount of IAA was low in the absence of L-tryptophan (Figure 4A). Enterobacter sp. TN38 showed minimal IAA production $\left(30.71 \mu \mathrm{g} \mathrm{mL}^{-1}\right)$ while Pseudomonas sp. TN36 showed the highest $\left(141.23 \mu \mathrm{g} \mathrm{mL} L^{-1}\right)$. Contrary to spectrophotometric detection, HPLC analysis (Figure 4B) showed low values of IAA produced by all five strains, with the highest detected in Azospirillum sp. TN10 $\left(9.2 \mu \mathrm{g} \mathrm{mL}^{-1}\right)$; this was found to increase with supplementation of L-tryptophan $\left(18.3 \mu \mathrm{g} \mathrm{mL}^{-1}\right.$; Figure $\left.4 \mathbf{B}\right)$.

\section{Potato Root Colonization and Growth Promotion Potential of Bacterial Strains}

The density of the bacterial populations in the potato rhizospheres changed in the different treatments at different growth stages of the plants. Bacterial populations were highest at the day of inoculation for all inoculants (>7.77 log CFU g ${ }^{-1}$ of rhizosphere sand). They then showed a continuous decline till day 60, except for the Azospirillum sp. TN10 and Enterobacter sp. TN38 strains, which maintained their population sizes at $\log 6.92$ and 6.27 $\mathrm{CFU} \mathrm{g}^{-1}$ of rhizospheric sand, respectively (Figure 5). No such bacterial populations were observed associated with the uninoculated plants.

Ultrastructure studies further confirmed the colonization of potato roots by the Azospirillum sp. TN10 inoculant. No bacterial cells were observed in the uninoculated control plants (Figure 6A). In the strain TN10 inoculated roots, bacterial cells 


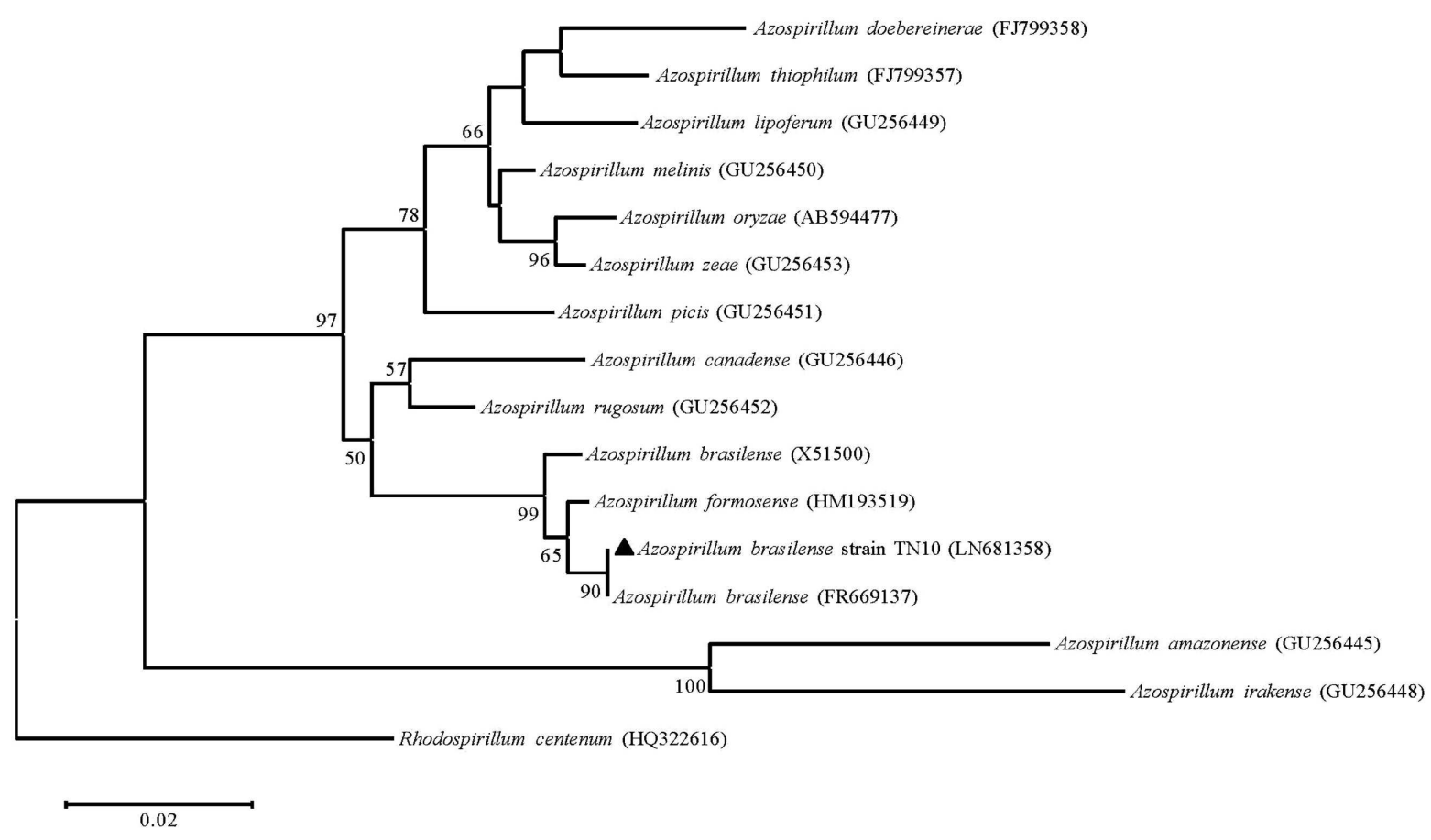

FIGURE 2 | Neighbor-joining phylogenetic tree based on nifH sequences (310 bp) of Azospirillum strains obtained from GenBank, including the nifH sequence of Azospirillum sp. strain TN10. Numbers at the branching points are bootstrap values $>50 \%$ (percentages of 1000 re-samplings). Rhodospirillum sp. served as the root. Bar shows sequence divergence of 0.02 nucleotides.

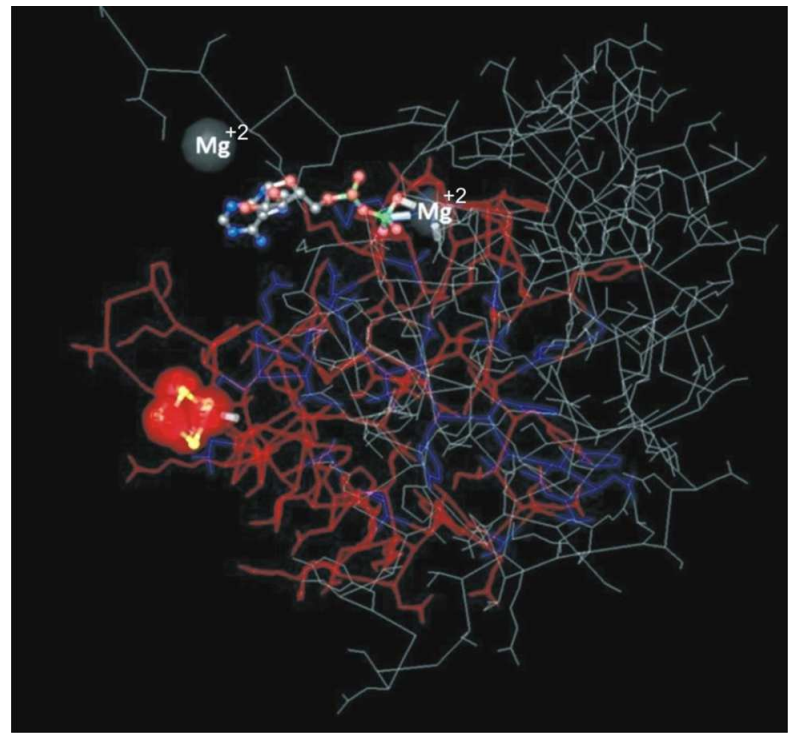

FIGURE 3 | Three-dimensional structure of Fe-nitrogenase protein of Azospirillum sp. strain TN10 based on 110 amino acids modeled using Cn3D software showing also the binding sites for $\mathrm{Mg}^{2+}$ which is suggestive of nitrogenase activity.

were found to be localized in the rhizosphere, in particular as attached cells on the root surface. However, no bacterial cells were observed inside the root cortical cells or the root hairs, showing that strain TN10 was not able to colonize the endosphere of potato (Figures 6B-D).

Overall, the inoculation with bacteria yielded significant positive effects on the plant growth parameters, including plant height, fresh and dry weight and total nitrogen levels (Figures 7A-D). Inoculation with Rhizobium sp. TN42 showed maximum increases in shoot length (85\%), while inoculation with Enterobacter sp. TN38 showed maximum increases (76\%) in root length (Figures 7A and 8). Inoculation with Azospirillum strain TN10 resulted in maximum increases in shoot and root fresh and dry weights (Figures 7B,C and 8). Specifically, this treatment showed $\approx 50 \%$ increases over the uninoculated control plants. Likewise, plants inoculated with Azospirillum sp. TN10 showed the highest $\mathrm{N}$ contents, both in the shoots and roots (3.98 and $2.1 \mathrm{mg} \mathrm{g}^{-1}$ dry wt). The uninoculated control plants showed the lowest $\mathrm{N}$ contents in both shoots and roots (Figure 7D).

\section{DISCUSSION}

The rhizosphere is a preferential niche for various types of microorganisms including a class of bacteria that are directly or indirectly beneficial for plant growth. The beneficial bacteria are designated as PGPR if they show different plant growth promoting properties, e.g., nitrogen fixation, phytohormone production, nutrient mobilization, or biocontrol abilities. The ultimate benefit of the use of PGPR is not only their plant growth promoting attributes, but also their environment friendliness and their cost-effective nature (Kaymak, 2011). Potato being 
A

400

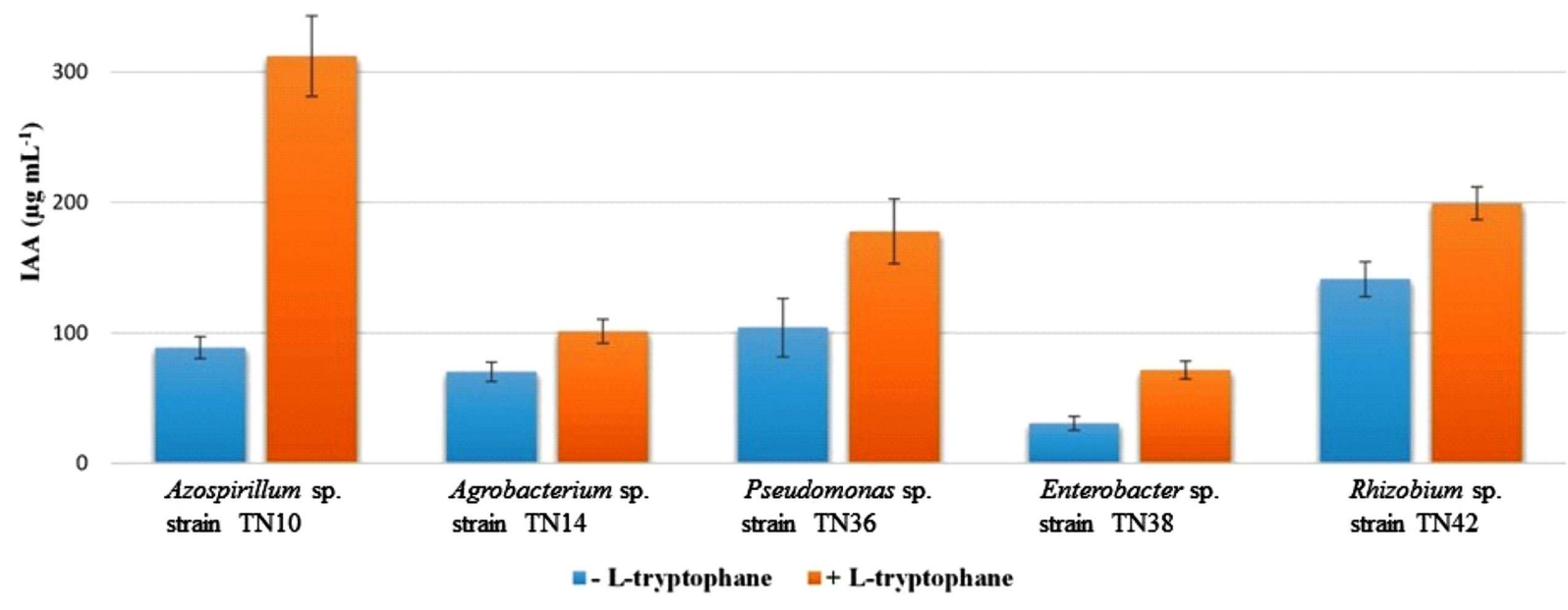

B 20

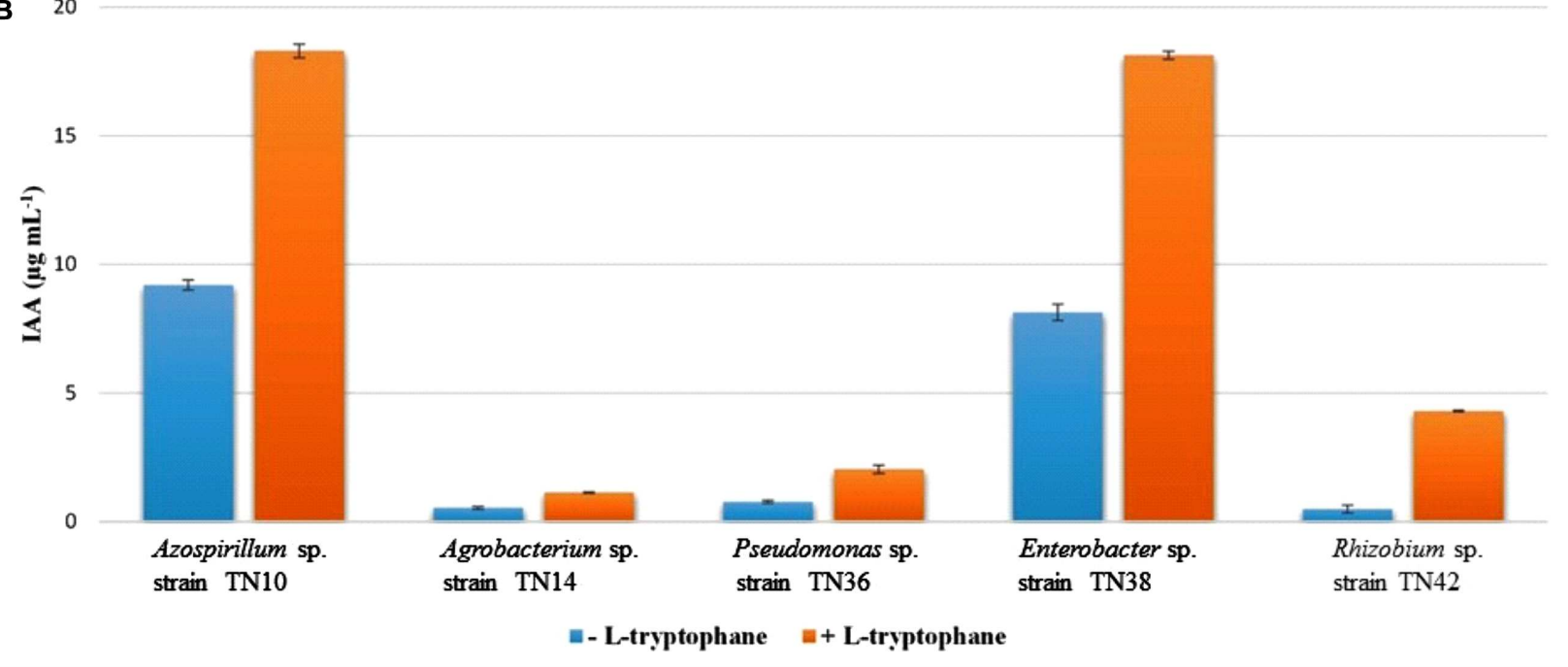

FIGURE 4 | Comparative quantification of IAA produced by bacterial strains isolated from potato using spectrophotometer (A) and HPLC (B). The values are means of three replicates. The standard errors of the means are represented as bars.

an important food commodity needs special attention and requires extensive fertilization. The Sahiwal and Jhang regions are located in central Punjab, which is the prime area for potato production in Pakistan. Main crop rotations in Sahiwal include potato-maize-maize, with the potato varieties including Simply Red, Kuroda, Cardinal, and Rodio. In Jhang, main crop rotations are potato-maize-maize and potato-maize-fallow, with main potato varieties being Desiree, Cardinal, Kuroda, Mutta, and Sante. In both areas, about $250 \mathrm{Kg}$ nitrogen and $150 \mathrm{Kg}$ each of phosphorus and potash is used per hectare for potato production. To overcome the expensive fertilizer application and reduce costs for poor farmers, we isolated five bacterial strains from the potato rhizosphere using NFM medium. Identification based on 16S rRNA gene sequence analyses showed that these isolates, TN10, TN14, TN36, TN38, and TN42, belong to known PGPR genera, i.e., Azospirillum, Agrobacterium, Pseudomonas, Enterobacter, and Rhizobium, respectively. Strain TN10 was identified as affiliated with A. brasilense, while for strains TN14, TN36, TN38, and TN42 species status could not be assigned. Phylogenetic analysis showed two main clusters, one encompassing $\alpha$-proteobacteria (including Agrobacterium, Rhizobium, and Azospirillum) and the other encompassing $\gamma$-proteobacteria, including Pseudomonas and Enterobacter. The Agrobacterium and Rhizobium strains form one subgroup as both are closely related. In fact, Agrobacterium strain TN14 clustered with the previously reported A. tumefaciens JN628031 and Rhizobium strain TN42 with Rhizobium sp. AF271637. In addition, $A$. brasilense strain TN10 grouped in a separate subcluster with A. brasilense FR667907 and Rhodospirillum sp. JN169775. Enterobacter sp. TN38 and Pseudomonas sp. 


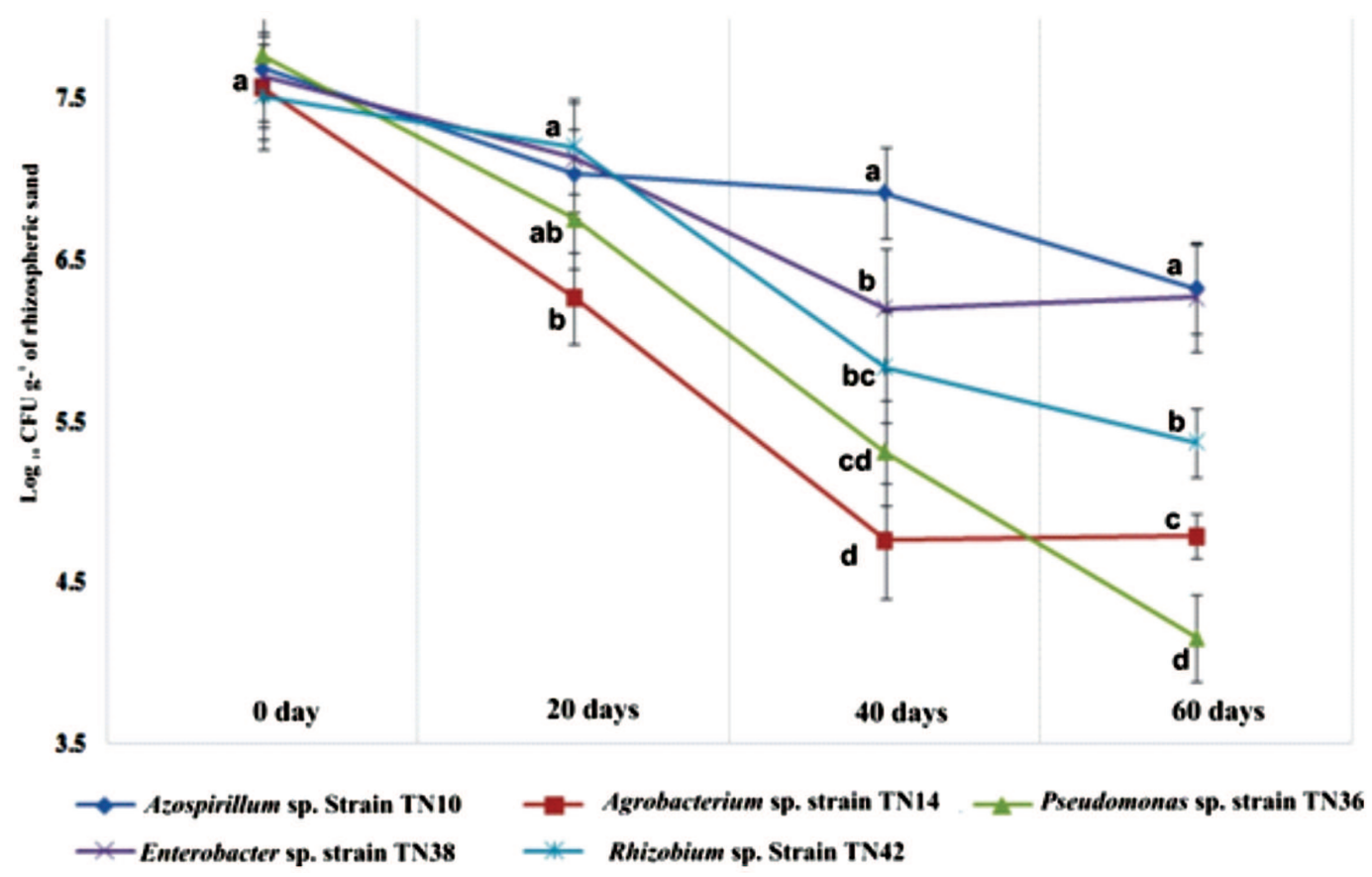

FIGURE 5 | Survival of different bacterial strains inoculated to potato (variety Kuroda) and population dynamics in the rhizosphere up to 60 days after inoculation. The values are means of three replicates. The standard errors of the means are represented as bars. Comparison between treatments was carried out by one-way analysis of variance (ANOVA). The means followed by different letters (a, b, c) at one specific time (e.g., 20 or 40 days) are significantly different at the $5 \%$ level of significance.
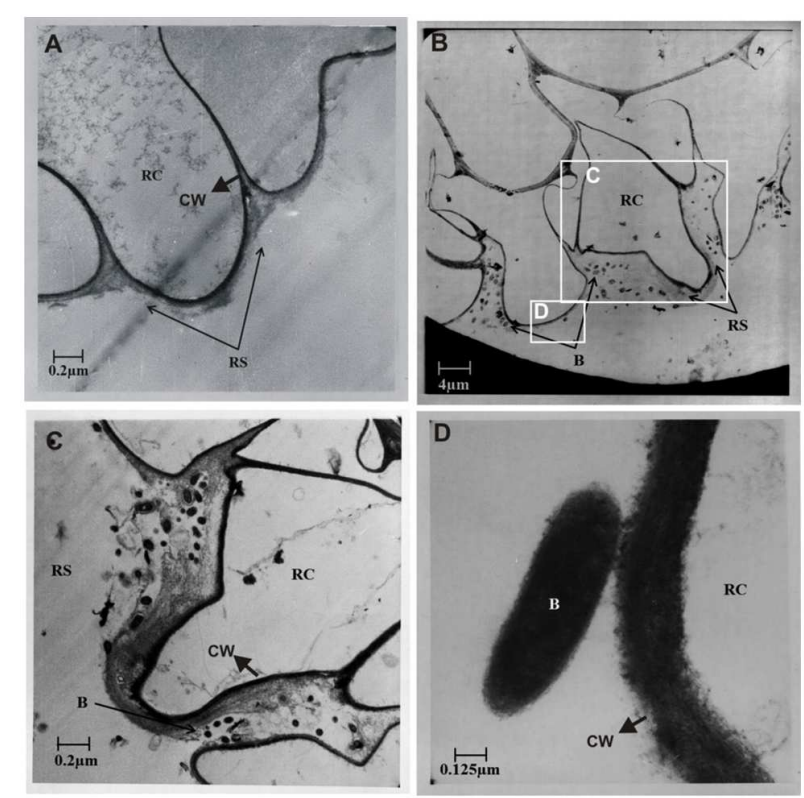

FIGURE 6 | Electron micrographs of in vitro grown root and rhizosphere sections of potato (variety Kuroda) from non-inoculated control plant (A) compared to plant roots inoculated with Azospirillum sp. strain TN10 (B). The bacterial attachment is evident on root surface within the rhizosphere and onto the cell wall. (C,D) Are magnified micrographs from (B) marked with white box. RC, root cell; RS, rhizosphere; B, bacteria; CW, cell wall.
TN36 clustered with E. cloacae NR118011 and Pseudomonas sp. EU158318, respectively, both belonging to the $\gamma$-proteobacteria. Several members of these genera are well-documented for their plant growth promoting activities at different crops (Leyval and Berthelin, 1989; Mehnaz and Lazarovits, 2006; Afzal and Bano, 2008; Shahid et al., 2012; Qaisrani et al., 2014).

Biological nitrogen fixation can account for $\approx 97 \%$ of $\mathrm{N}$ input into unmanaged terrestrial ecosystems (Galloway et al., 2008). Nitrogen-fixing bacteria are usually isolated on NFM, which may yield false positive results. Thus bacteria isolated from $\mathrm{N}$-free medium may not have the ability to fix nitrogen (Kuklinsky et al., 2004). Of the five strains isolated after repeated enrichment, only three, i.e., Azospirillum sp. TN10, Enterobacter sp. TN38 and Rhizobium sp. TN42, showed the ability to reduce acetylene to ethylene, while the Agrobacterium and Pseudomonas strains did not. Some of these N-free medium growing bacteria are efficient scavengers of traces of reduced nitrogen or they may be oligotrophs which grow on nitrogen fixed and released by other diazotrophs present in the mixed culture during the enrichment process (Tripathi et al., 2002). Phylogenetic analysis of the nifH gene of $A$. brasilense TN10 showed that it clustered with the nifH gene from $A$. brasilense FR669137. The 3D structure analysis revealed $77 \%$ similarities to the Fe-nitrogenase system of A. vinelandii showing also the binding sites for $\mathrm{Mg}^{2+}$, which is a requirement for nitrogenase activity along with dinitrogenase reductase, i.e., Fe-protein (Figure 3).

The effects of PGPR are often related to a manipulation of the network of plant hormones that are involved in growth 


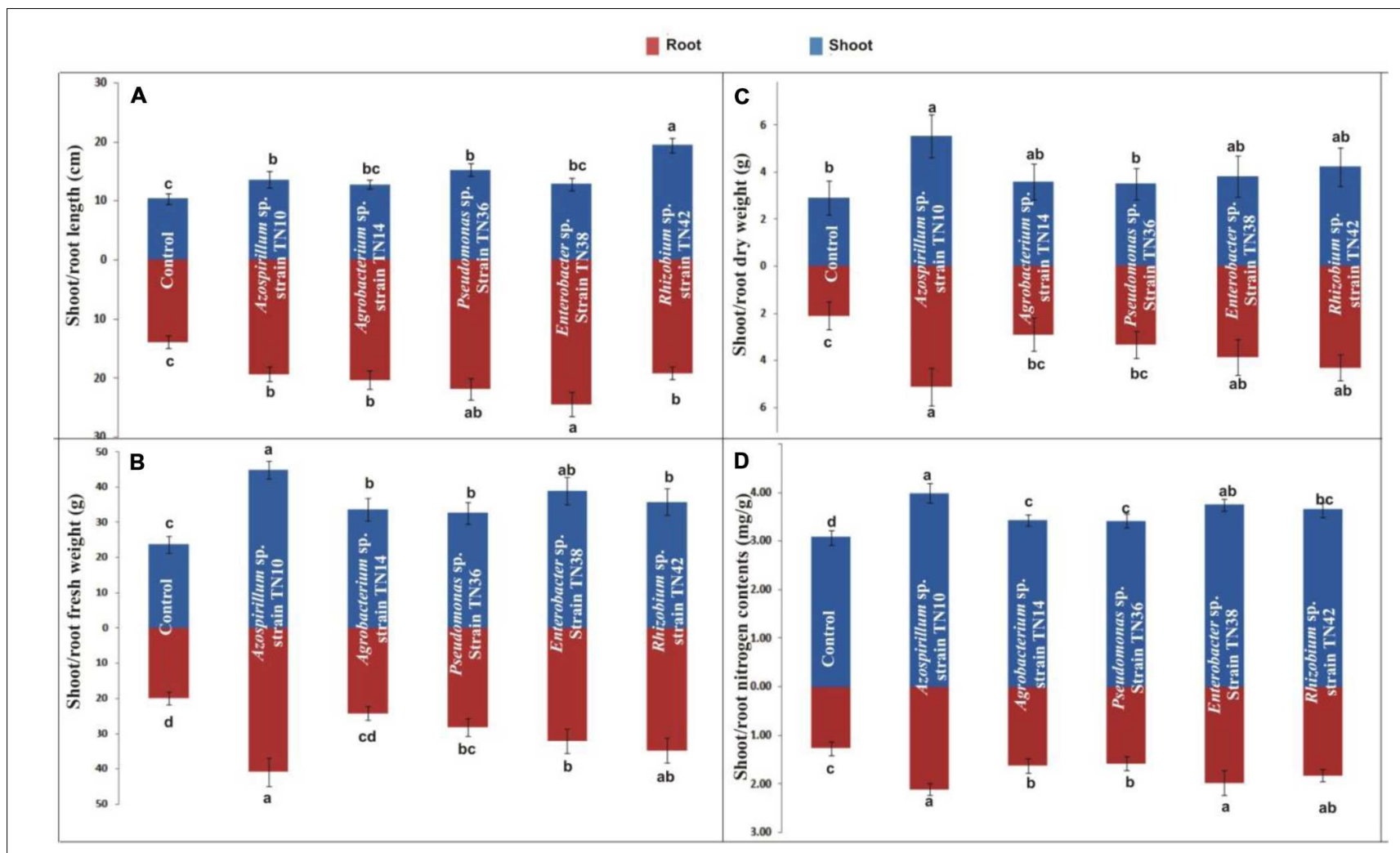

FIGURE 7 | Effect of bacterial inoculation on shoot and root length (A), fresh weight (B), dry weight (C), and nitrogen contents (D) of potato (variety Kuroda) grown in sterilized sand in pots. The values are means of three biological replicates. The standard errors of the means are represented as bars. Comparison between treatments was carried out by one-way analysis of variance (ANOVA). Values followed by different letters (a, b, c) are significantly different from each other at $5 \%$ level of significance.

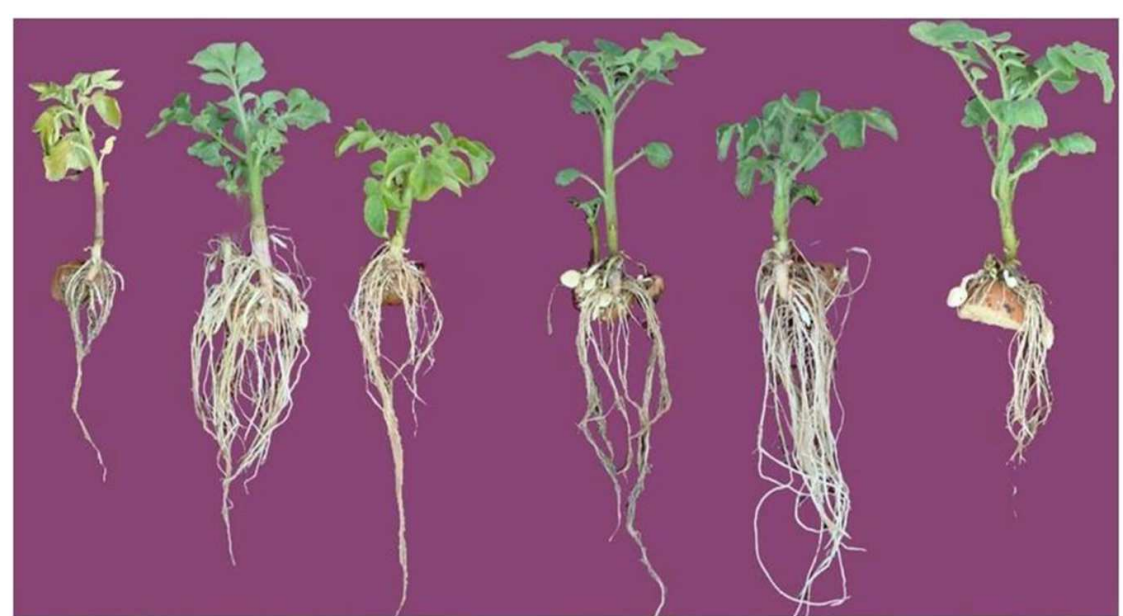

Control Azospirillum sp. Agrobacterium sp. Pseudomonas sp. Enterobacter sp. Rhizobium sp. strain TN10 strain TN14 strain TN36 strain TN38 strain TN42

FIGURE 8 | Representation of potato plant health and root system as affected by bacterial inoculation of seed tubers (variety Kuroda). Plants were harvested 60 days after sowing.

and stimulation of root formation (Pérez-Montaño et al., 2013). Here, only the biosynthesis of IAA was evaluated. There are many pathways resulting in IAA production in rhizobacteria; some have tryptophan as a main precursor while others have tryptophan-independent pathways (Spaepen et al., 2007). Two main types of detection techniques are widely used for 
IAA quantification: (I) a colorimetric method using Salkowski reagents, (II) a high performance liquid chromatography (HPLC) method (Sachdev et al., 2009). Addition of tryptophan can affect the amount of IAA produced, because most bacteria have the tryptophan-dependent pathway. However, the amount of IAA produced varies across strains and also with the concentration of tryptophan added (Gutierrez et al., 2009). IAA production was determined in both tryptophan supplemented and nonsupplemented medium by the aforementioned techniques. Addition of tryptophan increased IAA production in all strains, as shown by both assays, as reported earlier (Gutierrez et al., 2009). Contrary to the IAA concentrations observed by spectrophotometry, HPLC detected significantly lower concentrations in all strains. This may be attributed to the fact that Salkowski reagent can react with indole derivatives, thus giving false positive results (Kuang-Ren et al., 2003). Such indole derivatives have no role in plant growth, and hence the Salkowski assay is not adequate for the purpose of showing PGPR effects. It is useful, though, for screening large bacterial populations, as it is fast, thus reducing sample size, time and cost of eventual subsequent HPLC analyses.

Most strains exhibited multiple PGPR properties. These ultimately can provide benefits to plants in terms of stimulating growth. The variable innate PGPR potential of the strains may cause differential growth responses in plants (Ghyselinck et al., 2013; Qaisrani et al., 2014). We tested our bacterial strains only with respect to two traits, i.e., IAA production and nitrogenase activity. However, they might have potential for other PGPR traits which still need to be explored. In the plant inoculation assays, all bacterial strains improved plant growth as compared to the uninoculated control. Inoculation with Azospirillum strain TN10 exhibited maximum beneficial effects on plant growth, which we tentatively link to the ability of strain TN10 to fix nitrogen as well as produce high amounts of IAA. IAA can positively influence root elongation and lateral root development, which helps plants to acquire maximum water and essential nutrients. This may ultimately result in a well-established, vigorous and healthy plant. Bacterial strains producing phytohormones are known to influence the balance of plant phytohormones, eventually inducing different growth stages (Sturz, 1995) as well as, in an overall fashion, promoting plant growth (Ghyselinck et al., 2013). Greater plant dry weight production may also be ascribed to the enhanced leaf areas of the inoculated plants, especially the one inoculated with Azospirillum strain TN10, whereas greater shoot lengths reported may be positively correlated with greater photosynthetic rates and heightened transpiration efficiency because of availability of sufficient nitrogen, as compared to other plants (Byrd and May, 2000; Qaisrani et al., 2014). These results are consistent with those of earlier studies that show the effects of Agrobacterium, Pseudomonas, Enterobacter and Rhizobium on the growth of radish, French bean, sunflower, and rice, respectively (Ashrafuzzaman et al., 2009; Kaymak et al., 2009; Shahid et al., 2012).
The ability of bacterial inoculants to colonize plant tissue is an important factor to be addressed, because in the field the competition with other, indigenous, bacteria is tough. Here, all strains showed rhizosphere colonization and survival of up to 60 days. In particular, Azospirillum sp. strain TN10 showed high population densities and survival at the plant. In spite of the fact that the other strains showed a decline, apparently their population sizes up to 60 days were sufficient for the effects seen. Similar patterns of bacterial population declines were described by Fischer et al. (2010) in wheat. There may be several reasons for the fluctuations in bacterial population densities, with plant growth stage being a strong factor that affects the indigenous plant-associated communities in field-grown potato plants (Van Overbeek and Van Elsas, 2008). Azospirillum sp. strain TN10 showed relatively stable population sizes, which indicates it is a good root colonizer and PGPR in potato, as has been also reported for other crops (Steenhoudt and Vanderleyden, 2000; Guerrero-Molina et al., 2012; Qaisrani et al., 2014). Plant roots inoculated with Azospirillum sp. strain TN10, when examined by TEM, revealed strong bacterium-root associations. Adequate numbers of bacterial cells were thus present in the rhizosphere, and this may be related to the root area being rich in nutrients and having adequate micro-aerobic conditions that allow local nitrogen fixation to take place (Guerrero-Molina et al., 2012).

\section{CONCLUSION}

This is a basic study of screening the PGPR associated with potato rhizosphere. We have demonstrated that among all the PGPR obtained, Azospirillum sp. strain TN10 due to its innate potential to produce plant growth hormone and convert atmospheric nitrogen to plant usable form has potential to increase potato growth and nitrogen uptake. This strain can be a potential candidate for production of potato biofertilizer for integrated nutrient management.

\section{AUTHOR CONTRIBUTIONS}

TN conducted experiments and wrote manuscript, $\mathrm{SH}$ supervised the study, AI helped in exp. and edited manuscript, $\mathrm{MKH}$ and AM helped in analysis, JDE helped in pot experiment.

\section{ACKNOWLEDGMENTS}

This work was supported by HEC Pakistan under indigenous fellowship of Mr. TN. We would like to thank our Groningen partners, specifically Michele de Cassia Pereira e Silva and Mamoona Arshad, for their help with nifH analysis and the Biolog assays, and Mazhar Iqbal and Abdul Tawab for helping in the ARA. The authors also thank Javed Iqbal (Pr. Tech. TEM) for helping in ultra-structure studies. 


\section{REFERENCES}

Afzal, A., and Bano, A. (2008). Rhizobium and phosphate solubilizing bacteria improve the yield and phosphorus uptake in wheat (Triticum aestivum). Int. J. Agric. Biol. 10, 85-88.

Andreote, F. D., De Araújo, W. L., De Azevedo, J. L., Van Elsas, J. D., Da Rocha, U. N., and Van Overbeek, L. S. (2009). Endophytic colonization of potato (Solanum tuberosum L.) by a novel competent bacterial endophyte, Pseudomonas putida strain P9, and its effect on associated bacterial communities. Appl. Environ. Microbiol. 75, 3396-3406. doi: 10.1128/AEM.00491-09

Ardanov, P., Ovcharenko, L., Zaets, I., Kozyrovska, N., and Anna, M. P. (2011). Endophytic bacteria enhancing growth and disease resistance of potato (Solanum tuberosum L.). Biol. Control 56, 43-49. doi: 10.1016/j.biocontrol.2010.09.014

Arnon, D. I., and Hoagland, D. R. (1940). Crop production in artificial culture solution, sand and soil with special reference to factors influencing yield and absorption of inorganic nutrient. Soil Sci. 50, 463-483.

Ashrafuzzaman, M., Hossen, F. A., Ismail, M. R., Hoque, A., Islam, M. Z., Shahidullah, S. M., et al. (2009). Efficiency of plant growth-promoting rhizobacteria (PGPR) for the enhancement of rice growth. Afr. J. Biotechnol. $8,1247-1252$.

Bhattacharyya, P. N., and Jha, D. K. (2012). Plant growth-promoting rhizobacteria (PGPR): emergence in agriculture. World J. Microbiol. Biotechnol. 28, 13271350. doi: 10.1007/s11274-011-0979-9

Byrd, G. T., and May, P. A. (2000). Physiological comparisons of switchgrass cultivars differing in transpiration efficiency. Crop Sci. 40, 1271-1277. doi: $10.2135 /$ cropsci2000.4051271x

Calvo, P., Ormeño-Orrillo, E., Martínez-Romero, E., and Zúñiga, D. (2010). Characterization of Bacillus isolates of potato rhizosphere from andean soils of Peru and their potential PGPR characteristics. Braz. J. Microbiol. 41, 899-906. doi: 10.1590/S1517-83822010000400008

Cassán, F., Perrig, D., Sgroy, V., Masciarelli, O., Penna, C., and Luna, V. (2009). Azospirillum brasilense Az39 and Bradyrhizobium japonicum E109, inoculated singly or in combination, promote seed germination and early seedling growth in corn (Zea mays L.) and soybean (Glycine max L.). Eur. J. Soil Biol. 45, 28-35. doi: 10.1016/j.ejsobi.2008.08.005

David, T., Kenneth, G. C., Pamela, A. M., Rosamond, N., and Stephen, P. (2002). Agricultural sustainability and intensive production practices. Nature 418, 671-677. doi: 10.1038/nature01014

Food and Agriculture Organization (2014). The State of Food Insecurity in the World 2014: Strengthening the Enabling Environment for Food Security and Nutrition. Rome: Food and Agriculture Organization of the United Nations. Available at: www.fao.org.

Fischer, S. E., Jofré, E. C., Cordero, P. V., Mañero, Z. J. G., and Mori, G. B. (2010). Survival of native Pseudomonas in soil and wheat rhizosphere and antagonist activity against plant pathogenic fungi. Antonie Leeuwenhoek 97, 241-251. doi: 10.1007/s10482-009-9405-9

Galloway, J. N., Townsend, A. R., Erisman, J. W., Bekunda, M., Cai, Z., Freney, J. R., et al. (2008). Transformation of the nitrogen cycle: recent trends, questions, and potential solutions. Science 320, 889-892. doi: 10.1126/science.1136674

George, H., and Ed, H. (2011). A Summary of N, P, and K Research with Tomato in Florida. Gainesville, FL: University of Florida.

Ghyselinck, J., Velivelli, S. L., Heylen, K., O’Herlihy, E., Franco, J., Rojas, M., et al. (2013). Bioprospecting in potato fields in the central andean highlands: screening of rhizobacteria for plant growth-promoting properties. Syst. Appl. Microbiol. 36, 116-127. doi: 10.1016/j.syapm.2012.11.007

Guerrero-Molina, M. F., Winik, B. C., and Pedraza, R. O. (2012). More than rhizosphere colonization of strawberry plants by Azospirillum brasilense. Appl. Soil Ecol. 61, 205-212. doi: 10.1016/j.apsoil.2011.10.011

Gutierrez, C. K., Matsui, G. Y., Lincoln, D. E., and Lovell, C. R. (2009). Production of the phytohormone indole-3-acetic acid by estuarine species of the genus Vibrio. Appl. Environ. Microbiol. 75, 2253-2258. doi: 10.1128/AEM.02072-08

Hanif, M. K., Hameed, S., Imran, A., Naqqash, T., Shahid, M., and Van Elsas, J. D. (2015). Isolation and characterization of a $\beta$-propeller gene containing phosphobacterium Bacillus subtilis strain KPS-11 for growth promotion of potato (Solanum tuberosum L.). Front. Microbiol. 6:583. doi: $10.3389 /$ fmicb. 2015.00583
Hardy, R. W., Holsten, F. R. D., Jackson, E. K., and Burns, R. E. (1968). The acetylene-ethylene assay for nitrogen fixation: laboratory and field evaluation. Plant Physiol. 43, 1185-1207. doi: 10.1104/pp.43.8.1185

Hunziker, L., Bönisch, D., Groenhagen, U., Bailly, A., Schulz, S., and Weisskopf, L. (2015). Pseudomonas strains naturally associated with potato plants produce volatiles with high potential for inhibition of phytophthora infestans. Appl. Environ. Microbiol. 81, 821-830. doi: 10.1128/AEM.02999-14

Kaymak, H. C. (2011). "Potential of PGPR in agricultural innovations," in Plant Growth and Health Promoting Bacteria, ed. D. K. Maheshwari (Berlin: Springer), 45-79.

Kaymak, H. Ç., Güvenç, İ., Yarali, F., and Dönmez, M. F. (2009). The effects of biopriming with PGPR on germination of radish (Raphanus sativus L.) seeds under saline conditions. Turk. J. Agric. For. 33, 173-179.

Khosro, M., and Yousef, S. (2012). Bacterial biofertilizers for sustainable crop production: a review. J. Agric. Biol. Sci. 7, 307-316.

Kuang-Ren, C., Turksen, S., Ümran, E., Timmer, L. W., and Peter, P. U. (2003). Indole derivatives produced by the fungus Colletotrichum acutatum causing lime anthracnose and post bloom fruit drop of citrus. FEMS Microbiol. Lett. 226, 23-30. doi: 10.1016/S0378-1097(03)00605-0

Kuklinsky, S. J., Araújo, W. L., Mendes, R., Geraldi, I. O., Pizzirani, K. A. A., and Azevedo, J. L. (2004). Isolation and characterization of soybean-associated bacteria and their potential for plant growth promotion. Environ. Microbiol. 6, 1244-1251. doi: 10.1111/j.1462-2920.2004.00658.x

Leyval, C., and Berthelin, J. (1989). Interactions between Laccarialaccata, Agrobacterium radiobacter and beech roots: influence on $\mathrm{P}, \mathrm{K}, \mathrm{Mg}$, and $\mathrm{Fe}$ mobilization from minerals and plant growth. Plant Soil 117, 103-110. doi: 10.1007/BF02206262

Line, J., Hiett, K., Guard, J., and Seal, B. (2011). Temperature affects sole carbon utilization patterns of Campylobacter coli 49941. Curr. Microbiol. 62, 821-825. doi: 10.1007/s00284-010-9785-0

Lucas, J. A., Ramos Solano, B., Montes, F., Ojeda, J., Megias, M., and Gutierrez Mañero, F. J. (2009). Use of two PGPR strains in the integrated management of blast disease in rice (Oryza sativa L.) in Southern Spain. Field Crops Res. 114, 404-410. doi: 10.1016/j.fcr.2009.09.013

Majeed, A., Abbasi, M. K., Hameed, S., Imran, A., and Rahim, N. (2015). Isolation and characterization of plant growth-promoting rhizobacteria from wheat rhizosphere and their effect on plant growth promotion. Front. Microbiol. 6:198. doi: $10.3389 /$ fmicb.2015.00198

Mehnaz, S., and Lazarovits, G. (2006). Inoculation effects of Pseudomonas putida, Gluconacetobacter azotocaptans, and Azospirillum lipoferum on corn plant growth under greenhouse conditions. Microb. Ecol. 51, 326-335. doi: 10.1007/s00248-006-9039-7

Mohammed, T. A., Mervat, A. H., Hanan, H. Y., Gehan, H. Y., Mohamed, F., Mohamed, M., et al. (2013). Bio-preparates support the productivity of potato plants grown under desert farming conditions of north Sinai: five years of field trials. J. Adv. Res. 5, 41-48. doi: 10.1016/j.jare.2012.11.004

Müller, E. E., and Ehlers, M. M. (2007). Biolog identification of non-sorbitol fermenting bacteria isolated on E. coli O157 selective CT-SMAC agar. Water SA 31, 247-252.

Okon, Y., Albrecht, S. L., and Burris, R. H. (1977). Methods for growing Spirillum lipoferum and for counting it in pure culture and in association with plants. Appl. Environ. Microbiol. 33, 85-88.

Park, M., Kim, C., Yang, J., Lee, H., Shin, W., Kim, S., et al. (2005). Isolation and characterization of diazotrophic growth promoting bacteria from rhizosphere of agricultural crops of Korea. Microbiol. Res. 160, 127-133. doi: 10.1016/j.micres.2004.10.003

Pereira e Silva, M. C., Semenov, A. V., van Elsas, J. D., and Salles, J. F. (2011). Seasonal variations in the diversity and abundance of diazotrophic communities across soils. FEMS Microbiol. Ecol. 77, 57-68. doi: 10.1111/j.15746941.2011.01081.x

Pérez-Montaño, F., Alías-Villegas, C., Bellogín, R. A., Cerro, P. D., Espuny, M. R., Jiménez-Guerrero, I., et al. (2013). Plant growth promotion in cereal and leguminous agricultural important plants: from microorganism capacities to crop production. Microbiol. Res 169, 325-336. doi: 10.1016/j.micres.2013. 09.011

Poly, F., Monrozier, L. J., and Bally, R. (2001). Improvement in the RFLP procedure for studying the diversity of nifH genes in communities of nitrogen fixers in soil. Res. Microbiol. 152, 95-103. doi: 10.1016/S0923-2508(00)01172-4 
Qaisrani, M. M., Mirza, M. S., Zaheer, A., and Malik, K. A. (2014). Isolation and identification by 16s rRNA sequence analysis of achromobacter, azospirillum and rhodococcus strains from the rhizosphere of maize and screening for the beneficial effect on plant growth. Pak. J. Agric. Sci. 51, 91-99.

Reitz, M., Hoffmann-Hergarten, S., Hallmann, J., and Sikora, R. A. (2001). Induction of systemic resistance in potato by rhizobacterium Rhizobium etli strain G12 is not associated with accumulation of pathogenesis-related proteins and enhanced lignin biosynthesis. J. Plant Dis. Prot. 108, 11-20.

Sachdev, D. P., Chaudhari, H. G., Kasture, V. M., Dhavale, D. D., and Chopade, B. A. (2009). Isolation and characterization of indole acetic acid (IAA) producing Klebsiella pneumoniae strains from rhizosphere of wheat (Triticum aestivum) and their effect on plant growth. Indian J. Exp. Biol. 47, 993-1000.

Salema, R., and Brandao, I. (1973). The use of PIPES buffer in the fixation of plant cells, for electron microscopy. J. Submicrosc. Cytol. 5, 79-96.

Seldin, L., Rosado, A. S., da Cruz, D. W., Nobrega, A., van Elsas, J. D., and Paiva, E. (1998). Comparison of Paenibacillus azotofixans strains isolated from rhizoplane, rhizosphere, and non-root-associated soil from maize planted in two different Brazilian soils. Appl. Environ. Microbiol. 64, 3860-3868.

Shahid, M., Hameed, S., Imran, A., Ali, S., and van Elsas, J. D. (2012). Root colonization and growth promotion of sunflower (Helianthus annuus L.) by phosphate solubilizing Enterobacter sp. Fs-11. World J. Microbiol. Biotechnol. 28, 2749-2758. doi: 10.1007/s11274-012-1086-2

Shahid, M., Hameed, S., Tariq, M., Zafar, M., Ali, A., and Ahmad, N. (2014). Characterization of mineral phosphate-solubilizing bacteria for enhanced sunflower growth and yield-attributing traits. Ann. Microbiol. 65, 1525-1536. doi: 10.1007/s13213-014-0991-z

Simonet, P., Grosjean, M. C., Misra, A. K., Nazaret, S., Cournoyer, B., and Normand, P. (1991). Frankia genus-specific characterization by polymerase chain reaction. Appl. Environ. Microbiol. 57, 3278-3286.

Spaepen, S., Vanderleyden, J., and Remans, R. (2007). Indole-3-acetic acid in microbial and microorganism-plant signaling. FEMS Microbiol. Rev. 31, 425448. doi: 10.1111/j.1574-6976.2007.00072.x

Steel, R. G. D., Torrie, J. H., and Dickey, D. A. (1997). Principles and Procedures of Statistics, A Biometrical Approach, 3rd Edn. New York, NY: McGraw Hill Book Int. Co, 172-177.

Steenhoudt, O., and Vanderleyden, J. (2000). Azospirillum, a free-living nitrogenfixing bacterium closely associated with grasses: genetic, biochemical and ecological aspects. FEMS Microbiol. Rev. 24, 487-506. doi: 10.1111/j.15746976.2000.tb00552.x

Sturz, A. V. (1995). The role of endophytic bacteria during seed piece decay and potato tuberization. Plant Soil 175, 257-263. doi: 10.1007/BF000 11362

Tailor, A. J., and Joshi, B. H. (2014). Harnessing plant growth promoting rhizobacteria beyond nature: a review. J. Plant Nutr. 37, 1534-1571. doi: 10.1080/01904167.2014.911319

Tamura, K., Stecher, G., Peterson, D., Filipski, A., and Kumar, S. (2013). MEGA6:molecular evolutionary genetics analysis version 6.0. Mol. Biol. Evol. 30, 2725-2729. doi: 10.1093/molbev/mst197

Tien, T. M., Gaskins, M. H., and Hubbell, D. H. (1979). Plant growth substances produced by Azospirillum brazilense and their effect on the growth of pearl millet. Appl. Environ. Microbiol. 37, 1016-1024.

Tripathi, A. K., Verma, S. C., and Ron, E. Z. (2002). Molecular characterization of a salt-tolerant bacterial community in the rice rhizosphere. Res. Microbiol. 153, 579-584. doi: 10.1016/S0923-2508(02)01371-2

Van Overbeek, L. S., and Van Elsas, J. D. (2008). Effects of plant genotype and growth stage on the structure of bacterial communities associated with potato (Solanum tuberosum L.). FEMS Microbiol. Ecol. 64, 283-296. doi: 10.1111/j.1574-6941.2008.00469.x

Vincent, J. M. (1970). A Manual for the Practical Study of the Root Nodule Bacteria. Leicester: Burgess and Son Ltd.

Weisburg, W. G., Barns, S. M., Pelletier, D. A., and Lane, D. J. (1991). 16S ribosomal DNA amplification for phylogenetic study. J. Bacteriol. 173, 697-703.

Conflict of Interest Statement: The authors declare that the research was conducted in the absence of any commercial or financial relationships that could be construed as a potential conflict of interest.

Copyright (C) 2016 Naqqash, Hameed, Imran, Hanif, Majeed and van Elsas. This is an open-access article distributed under the terms of the Creative Commons Attribution License (CC BY). The use, distribution or reproduction in other forums is permitted, provided the original author(s) or licensor are credited and that the original publication in this journal is cited, in accordance with accepted academic practice. No use, distribution or reproduction is permitted which does not comply with these terms. 